Article

\title{
The Concept of Periphery in Pope Francis’ Discourse: A Religious Alternative to Globalization?
}

\section{Pasquale Ferrara}

Secretary General and collaborator to the Robert Schuman Centre for Advanced

Studies-ReligioWest, European University Institute, Via Bolognese 156-50138 Florence, Italy; E-Mail: pasquale.ferrara@eui.eu; Tel.: +39-055-4685-313

Academic Editor: Lionel Obadia

Received: 21 October 2014 / Accepted: 24 December 2014 / Published: 16 January 2015

\begin{abstract}
Since the beginning of his mandate, Pope Francis has used the concept of periphery as a metaphor of social marginality. However, the notion of periphery also seems to target the asymmetries generated by the liberal version of globalization. Pope Francis' narrative has to be read in the broader context of the relation between religions and globalization. That interaction is usually conceptualized in terms of religions capitalizing on global "vectors", such as new information and communication technologies, processes of political and institutional integration, shared cultural patterns, transnational phenomena and organizations. An alternative way to analyze the role of religions consists in considering them as agencies defending the perspective of a universal community, putting into question the national political boundaries and contesting the existing global order. Understood in those terms, the concept of periphery reveals to be a powerful rhetoric device, insofar as it suggests that it is possible to get a wider perspective of the current state of the world looking form the edge rather than from the center.
\end{abstract}

Keywords: religions and globalization; religions as resistance; world community; peripheries; expulsions; difference

\section{Introduction}

One recurrent topic in the discourse of Pope Francis, since his election on 13 March 2013, has been that of the "periphery". Rather than a geo-political or geo-economic concept, the idea of a "periphery" seems to refer, in Pope Francis' view, to the broader and deeper notions of exclusion, alienation, and 
expulsion. It has more to do, perhaps, with human security than with power hierarchy and polarity in a world of states. However, to the extent that the "periphery" implies the existence of a "center", it also seems to target the asymmetries generated by the liberal version of globalization. From this point of view, the Pope's discourse sounds as a critical appraisal of the world order (or disorder). Beyond the religious-normative interpretation of the political and economic structure of the world, in this paper I will try to compare the Papal narrative on the periphery to several theoretical approaches to the international relations, not to suggest that there are immediate similarities, but rather to signal that the concept of periphery has a considerable tradition in the study of international relations and that this very tradition could be useful to analyze the implication to the Francis' insistence on that notion. From the methodological point of view, I need to clarify from the outset that I will try to establish broad analogies rather than overlapping conceptualizations of the metaphor of periphery. All the same, I believe that the parallelism is extremely helpful in contextualizing the Papal discourse in the analytical frameworks of the international relations theory, in particular when inequalities and asymmetries are addressed.

Furthermore, it is my intention to discuss whether this idea of the periphery-certainly not entirely new, in the substance if not in the terminology in the Catholic social thought - could be, in turn, a new way of outlining an alternative worldview consisting in rethinking the present state of affairs of the world starting from the periphery rather than from the "headquarters" of global politics. As a background of this attempt I will intentionally emphasize that part of the religious message that can be read in terms of "resistance" of "critical actors" to the idea of globalization embedded in the current world's political and economic structure.

\section{Religions and Globalization}

The study of the influence of religions on international relations is now definitively considered a robust field of research with a relevant role in the International Relations Theory. Since the seminal studies of Gilles Kepel [1], José Casanova [2], Peter Berger [3], religions have been conceptualized in terms of their "return" (Fabio Petito and Pavlos Hatzopoulos) [4], "revenge" (as in Kepel's work) "resurgence" (Scott Thomas) [5] non only as the "missing dimension of statecraft" (Douglas Johnston and Cynthia Sampson) [6] and in terms of a post-secular turn in domestic political systems, but also, and more importantly, in the analysis of the international order and the new "struggle for identity" in the global arena.

The literature on the role of religions on the international scene is vast and articulated in several strands of research. Prominent scholars like Eric O. Hanson [7] and Jeffrey Haynes [8,9] provided comprehensive and persuasive frameworks for the study of religions in the international relations.

In particular, research on religions appears to be more and more connected, to the one side, to the study of globalization and global politics [10] and, to the other side, to world affairs or world politics [11]. This paper is not the right venue where such a distinction between "global politics" and "world politics" can be analyzed in depth; however, it is quite clear that whereas globalization implies, to some extent, an increasing "westernization" of the economic, technological and communicational patterns on interactions in the world, by world politics it is rather meant a more pluralistic system of 
relations among states, civil society organizations, multinational firms, epistemic communities, playing different but strictly interrelated roles.

The relation between religions and globalization is sometimes represented in terms of religions capitalizing on global "vectors", such as new information and communication technologies, processes of political and institutional integration, shared cultural patterns, transnational phenomena and organizations. According to this narrative, religions are using the new languages of the global community for conveying their messages and promoting their agendas, even though this process implies the loss of cultural roots and a reduced aptitude to frame religious beliefs in the new historical and societal context. [12] Even in the case of religious fundamentalism [13] and political intolerance based on religious conceptions (or misconceptions), the tools of liberal globalization-ironically-are seen as means for promoting and disseminating a radical anti-Western ideology. When it comes to the need of "spreading the word", no contradiction is perceived in recurring to all technical and political devices provided by modernity, even though it is exactly such a modernity the main political and ideological target of religious (and sometimes violent) radicalism.

In this domain the thesis of the "ambivalence of the Sacred" first proposed by Scott Appleby [14] and further developed by other Authors [15] receives one more confirmation. The latest, tragic example of such double track as far as western technology is concerned, in combination with an instrumental (and even lethal) approach to transnationalism, is provided by the surge of the ISIS in Iraq and Syria. It is however a matter of discussion if it is exactly that ambivalence that takes more and more the form of a "sacred violence" [16] or it is the quest for power to be inherently ambivalent, making use of religion - among other factors - as a pretext or as a mechanism for legitimation [17].

On a quite different ground, religions are sometimes conceived as tools to be used in the processes of conflict resolution and reconciliation [18], as it happens in the studies that try to connect interfaith dialogue and peace-building [19-21] or, at the other extreme, as a primary causal factor of intolerance, violence and conflict intractability. These approaches are both directly or indirectly linked to the current agenda of international relations, and as such they do not offer a vision of global religions detached from current events in the global arena. A third way to conceptualize religions is to link them to the global impact of diasporas (understood as "travelling cultures" [22]) in many societies, mainly in Western countries, and to the waves of migrations that are causing internal tensions in several societies (especially in Europe [23]) that used to understand themselves in terms of cultural and religious homogeneity due to historical factors and ancient traditions.

\section{Religions and the "Higher Order"}

In acknowledging the relevance of these studies and approaches for a deeper understanding of the global outreach or religions, I find more promising for a more articulated reading of the global role of religions today the researches that stress the link between religions and universally inclusive meaning of religious ideas, from the one side, and between religions and transnational societies, from the other [24].

In the first case, religions are supposed to be potentially a universal glue for an increasingly post-global world, where identities are being crafted as societal structures that resist globalization: "in addition to a congeries of different religions in the world it will be essential for there to be some 
overarching sense of order and respect. The worldview that is emerging for the global world therefore, is in essence a kind of higher order" ([25], p. 124). Although the idea of a "higher order" becoming a shared worldview is speculative, "yet the necessities of global interaction may force it upon us. The threat of globalization is that it tries to get everyone doing the same thing and thinking alike. In some ways the world is becoming too compact. The idea of a global higher order has the advantage of not imposing a single ethic or ethos on the rest of the world, except for the higher-order pattern of civility. It may be the coming global civilization.” ([24], p. 131).

The problem with the perspective of the 'higher order' is that it must face the fact that the present structure of the international system, with all the emphasis on international institutions and multilateralism, is still state-based and Westphalian. The compatibility of such a structure with the universal claims of religions has being put under stress in the case of the so-called "transnational religions", meaning "religious traditions with universal pretensions and global ambitions" ([26], p. 7). In particular, Islam, Christianity and Buddhism are "transnational religions" or "religions of expansions" ([25], p. 7) operating in a world of securitized and heavily guarded borders, separated political units and closed welfare systems. In a way, religions are to be seen as "new transnational nations" ([27], p. 10).

Should the "higher order" paradoxically be articulated in the framework of the existing order? In that case, what will become of its supposed transcendence? It seems plausible that religions simply overlook the problems connected to the deconstructing of an exclusive Westphalian order (based on the "exclusionary sovereign state" [28]) to concentrate more on the possible articulation of a reconstructed system of meaning at global level. In the view of Richard Falk, "the religious framing of reality is rooted in the present, but also hopeful about an eventual deliverance from suffering and privation. Indeed, the central founding narratives of the world's great religions are preoccupied with liberation from oppressive social and political arrangements, promising that adhering to faith, emancipation will be found despite the seeming overwhelming weight of oppressive structures"([29], p. 160). Religions can join forces with other agencies in order to bring about a fundamental change in the patterns of globalization: "[A] religious/spiritual orientation needs to inform the energies of civic globalization if such transformative approaches to world order are to have any serious prospect of effectively launching a political project that offer an alternative to that being foreshadowed and actualized by the largely economistic forces and collaborative geopolitical forces associated with corporate globalization and empire-building." ([27], p. 163).

The higher order is to be seen, therefore, not only as a new horizontal articulation of interactions and connection at global level, but also as the common endeavor of ethical and spiritual agencies working together to forge an alternative and inclusive world order [30].

\section{Religions and Problem-Solving}

As recalled above, one easy way to solve the growing contradiction between the inter-state structure of world politics and the universalistic perspective of religions is to conceptualize the latter as variables capable to play a role in complex pre-conflict or post-conflict environments. This is not to suggest that religions are seen, in that perspective, as "global NGOs", a sort of spiritual "Red Cross" intervening in deeply divided society in view of reconciliation and forgiveness. On the contrary, religions are sometimes considered strong societal actors exerting a political influence in reconstructing 
governance and institutional frameworks. The issue here is not the dignity of religions in that scheme; rather, the point is that religions are understood through the conceptual lens of a problem-solving approach to international relations [31]. Religions are considered valuable in conflictive environments or reconciliation schemes insofar as they are available to play whatever role compatible with their general goals.

What is mostly neglected is the function of religions as critical actors with a reflexive attitude toward the existing political order, rather than only addressing its dysfunctions and fixing its inefficient features [32]. This proactive role of world's religions is evident in relation to the issues of the so-called "global governance", and in particular on the occasion of international summits such as the G8 and G20; in several instances, religious leaders gathered at their initiative to discuss items on the agenda of such summits, producing articulated documents containing proposal for actions and initiatives to be taken by the international community ([23], pp. 37-38).

It is important to retain that religions in the global arena are still understood and conceptualized within the existing paradigms of the international relations theory. In the rationalist reading, religions are, at best, useful tools for crisis management and for reaching out to non-cooperative actors, not to mention their potential function as legitimizing agencies towards existing or consolidating political order. In the post-positivist reading, on the contrary, religions are understood as actors contesting the status quo in connection with the diminishing role that states are now playing in the international arena, and providing a different narrative of what should be consider as "order", if we need any. According to the methodology of social science, post-positivist analysis of the role of religions is correctly conducted independently from their dogmatic stance on several ethical issues. What remains to be further explored is whether religions can be relevant for the international order because of their inherently religious and normative approach, rather than only in terms of their performance in the perspective of an utility function. I will discuss such a possibility in the following paragraphs.

\section{Religions as Critical Actors}

My main point is that there must be a way to analyze the role of religions as critical actors contesting the legitimacy of the present form of globalization without losing sight of their nature as "comprehensive visions" of the world. I believe that this task can be accomplished by referring to religions as agencies defending the perspective of a universal community as opposed to or at least an indispensable development of a globalized society. From this point of view, religions are building on a tradition of resistance to the hegemonic powers related to the modern state and, more generally, to the segmentation of the political realm in separated territories and divided political institutions: "the concept of world community has fulfilled an important critical function within the history of political thought, sometimes to the point of being a condition of possible resistance. Whenever modern political institutions and practices are resisted in the name of mankind, this usually implies not only that these institutions and practices go against the best interests of humanity, but also that they help reproduce those forms of authority that keep mankind divided" [33]. The resistance to the political power in the framework of sovereignty has been articulated by the theories of world community "in the context of cosmological beliefs about the human habitat and the role of mankind within this habitat" ([32], p. 181) The substitution of the notion of international relations with that of "world politics" do not 
address the fundamental problem of an alternative model of global governance: "It is evident that, by semantic logic, a world politics must imply the transcendence of the 'international', defined in terms of the anarchic pluralism of particularistic political entities, in favor of some form of political universality, yet how this transcendence is to be thought remains rather obscure." [34]. The general assumption of this form of universalism is that there is a binary choice to be made between a political domain structured either "anarchically, with no overarching authority over these particularistic entities, or hierarchically, through the establishment of some universal structure of authority" ([33], p. 216). It is evident that the universalization of the political authority runs the risk to replicate at a global scale the structures of political domination and control that govern the internal order of states ([33], p. 216). A truly universalistic perspective must deal with the fundamental constrains of the existing political forms such as states, international organizations, and other intergovernmental agencies that deal even with the idea of equality through the analytical lens of the identity, spatially determined and dependent upon social-economic arrangements of established powers. The idea of world community builds on a different form of "generic universalism", detached from any institutional existing framework: "Consigned to indiscernibility in the encyclopedia of contemporary global politics, the existence of the world community may be verified by concrete local practices that are able to force a momentary illumination of the truth of generic equality that the statist logic of the political obscures." ([33], p. 244). World community should not be represented "in terms of the political unification of the entire humanity but as a process of the unfolding of the anti-statist and egalitarian being-in-common" ([33], p. 244). Theories of world community differ in epistemological (as far as the instruments of analysis are provided by disciplines as diverse as philosophy, international relations theory, anthropology, and even theology) and hermeneutical terms (since the accounts of the "path of history" imply divergent readings of events and social and institutional change at global level), but perhaps they share the idea that there is a structural and mutual implication between the categories of the universal and the particular. More specifically, three basic assumptions emerge from the theorizations of a world community: first, they are based "on the idea that universalistic and particularistic form of community are co-constituted in time, and that they are also interpenetrating"; second, such theories usually "assume that there is some form of isomorphism between the universal community of all mankind and the individual communities that compose it" and that implies, at the lowest level of comparison, a degree of human sociability and rationality, so that practices occurring within communities also apply in the relations between them; third, theories of world community "assume that all societal relations between individual human beings as well as the relations between the communities they inhabit are essentially embedded within a universal community of all mankind" ([32], p. 172). Co-constitution, isomorphism and embeddedness are three features that specify and make substantial the idea of a world community also form the point of view of a religious perspective. The main difference of this approach vis-à-vis other conceptions of the world order could be illustrate by the example of English School of International Relations. According to Hedley Bull [35], for instance, at international level we are witnessing an evolution from an "international society of states" towards a more pluralistic "world political system" in which also non-state entities play a primary role. For the structural conception or world community, on the contrary, shared by many religious faiths, the fundamental unity of the societal and political space at global level was always present, despite the division of mankind in separate political units. 


\section{Religions as Resistance}

The conception of a trans-boundary universal community spread on the planet doesn't always translate in a contestation of the political order, but at times it fulfills the function of a form of resistance to modern political institutions. Such a resistance has to be understood, ontologically, "in the contexts of cosmological beliefs about the human habitat and the role of mankind within this habitat" ([32], p. 181). It is a resistance that makes sense only if it is articulated from "a cosmological vantage point situated over and above the plurality of human communities and the multitude of individual human beings" ([32], p. 181).

This form or "resistance" is quite different from the exemplar attitude of nonviolent religious persons or "principled pacifists" in contemporary times, like the Mahatma Gandhi or, to some extent, personalities with more plural political roots and changes of pragmatic orientation, as in the case of Nelson Mandela. It is also dissimilar to the militant engagement of influential intellectuals like Dietrich Bonhoeffer, who chose the path of a "costly discipleship", resorting also to acts of "necessary" violence in case of macroscopic and patent injustice, unbearable oppression and structural violence [36].

By resistance I mean a different concept, more related to the infrastructure of the contemporary international realm. In practical terms, religions tend today to provide the rationale for a resistance to the standard version of globalization. Such an attitude might take the feature of a protest or even open rebellion to the political power and to the hegemonic discourse of liberal institutions. Contrary to the loyalist tradition of the past, especially in the area of Christianity, religions are interpreting their role in term of critical agencies towards the "market failures", the growing global inequality and the loss of ethical perspective in individual and social life. However, this is not a new function for religions and for any comprehensive vision of the world or any holistic conception of mankind. In fact, one may say that any version of the political philosophy of cosmopolitanism is, in its essence, a way to re-assess the "partition" of he world community from an integrative ideal "state of nature". More concretely, a distinction can be made between weak and strong cosmopolitanism. According to Brock and Brighouse, "weak cosmopolitanism just says that there are some extra-national obligations that have some moral weight. Strong cosmopolitanism, by contrast, claims that, at the most fundamental level, there are no society-wide principles of distributive justice that are not also global principles of distributive justice"([37], p. 3). In the words of Pope Francis, "with due respect for the autonomy and culture of every nation, we must never forget that the planet belongs to all mankind and is meant for all mankind; the mere fact that some people are born in places with fewer resources or less development does not justify the fact that they are living with less dignity" ([38], p. 150, paragraph 190).

What appears to be new is the fact that "virtually every religious tradition has been touched by religious forms of political protest - from American Christianity and Israeli Judaism to Indian Hinduism and Japanese Buddhism; it is not purely a product of the Islamic activism of the Middle East"([39], p. IX). Religions produce, together with political and institutional loyalism, a new kind of religiously engaged people, "religious activists", defined as "individuals with both religious and political interests. To understand their perspective is an exercise in both comparative religion and comparative politics, for they appear to be responding in a religious way to a political situation" ([39], p. 6). 
This phenomenon is to be conceived as a form of category of action with several distinctive features shared by disparate religious movements and environments all around the world. The first fundamental character of these movements is the challenge to the secular state, marking a profound comparative difference against the religious revival occurred in the second half of the XX century during the process of de-colonization, essential based on forms of nationalism or claim of solid national identity.

The second distinctive element is the fact that the religious resistance is globally spread and not limited to one religion or even to the "fundamentalist" or radical version of it. It regards phenomena-unfolding in the decades between the XX and XXI century-as diverse as Muslim rebellion in Egypt, the Iranian revolutionary paradigm, the Israel's militant Zionism, Hamas and the Islamic Intifada, insurgency in Iraq, resurgent Islam in South and Central Asia (Afghanistan, Pakistan, Hindu nationalism), Buddhist revolts in Sri Lanka, Mongolia, Tibet, Burma, the Militant Christian right in the United States, the global Jihad. What is appealing in all these movements is their promise to enable people to reclaim a better life. In the words of Juergensmeyer, "the empowerment granted by religious violence is especially appealing to those who have not had power before. The Iranian revolution is a potent example. Beneath the clerical exclusivity of the ayatollah's regime was a genuine social revolution, one that has had an effect on all levels of Iranian society" ([39], p. 220). However, the rebellion is not always taking the form of violent opposition; in most cases, resistance means, in a more profound sense, the search for a radical alternative to the liberal and mostly Western form of globalization. The formation of an "antiglobal religion" [40] has been observed, for instance, at the occasion to the fist wave of social protest against the World Trade Organization starting from its official meeting in Seattle in 1999, opposing the so-called ideology of one-worldism in the name of the alter-globalism. One effective slogan of Christian alter-global movements is, for instance, globalize solidarity.

\section{The Center-Periphery Discourse between Theory and Practice}

The process of de-coupling regions from globalization without losing sight of the universalist claim of religious beliefs has recently seen the Catholic Church in the forefront of the constructive-critical side of the present (dis)order. Pope Francis defined himself, in his first improvised address to the crowd in St.Peter's Square immediately after his election, as a Pontiff chosen "almost to the ends of the earth" [41] There in an apparent similarity with the first words of Pope John Paul II, who chose to introduce himself to the crowd in the very same Square in the night of his election as "a Pope who comes from a far away country" [42]. The "faraway" was less the periphery of the world (capitalist and liberal) than the border of another world (communist and illiberal). However, not even the periphery mentioned by Pope Francis can be truly conceptualized in the trivial meaning of the word, that is, in pure geographical or geo-economic terms; at least, there is no evidence that Pope Bergoglio understands its own country as "peripheral". In fact, Argentina in a member of the G20 and certainly not a marginal country in the international system, notwithstanding repeated financial turmoil, and in any case it is one of the most important countries in Latin America, with an influential political role at a regional level in competition/cooperation with Brazil.

It is true that Francis is the first non-European Pope in many centuries [43] although it would be hard to maintain that he is also non-Western, in consideration of his cultural and even familiar background. 
The reference to the periphery is a metaphor that goes much deeper than a geographical coordinate. As Francis says, "I am convinced of one thing: the great changes in history were realized when reality was seen not from the center but rather from the periphery. It is a hermeneutical question: reality is understood only if it is looked at from the periphery, and not when our viewpoint is equidistant from everything. Truly to understand reality we need to move away from the central position of calmness and peacefulness and direct ourselves to the peripheral areas. Being at the periphery helps to see and to understand better, to analyze reality more correctly, to shun centralism and ideological approaches..." ([44], pp. 3-4). There is here not only a clear preference for an interpretation of the world that is de-centralized and non-hegemonic, but also a strong - although implicit — contestation of the prevailing and power-centered vision of the world itself. Beyond the curtains of the official history - seems to suggest Pope Francis - an alternative course of that same history is at work, and it is this neglected and marginalized side that is worth exploring to truly understand the unfolding story of mankind as a whole.

More fundamentally, Pope Francis intends to anchor his reflections on the direct experience of the true life of and in the periphery. "This is really very important to me: the need to become acquainted with reality by experience, to spend time walking on the periphery in order really to become acquainted with the reality and life-experiences of people. If this does not happen we then run the risk of being abstract ideologists or fundamentalists, which is not healthy." ([43], p. 4)

Cardinal Bergoglio made the case for reaching out to the peripheries at the very eve of his election as the successor of Benedict XVI: "The Church is called to come out of herself and to go to the peripheries, not only geographically, but also the existential peripheries: the mystery of sin, of pain, of injustice, of ignorance and indifference to religion, of intellectual currents, and of all forms of misery." [45].

The semantic content of the notion of periphery is quite wide and obviously not limited to urban marginalities, although the image of the misery of the suburbs of Buenos Aires certainly is always in the background (not only las villas in Buenos Aires, but also the favelas in several Brazilian metropolis or the poblaciones callampa in Santiago de Chile). "Francis uses 'peripheral' in different ways, always positive. He warns the church not become so fixated on the center that it neglects the periphery-those people who live on the edge of mainstream society, whether within the economically advanced nations, or globally. That 'edgy' quality might result from poverty, from racial categories, or from sexuality and life-style. Although not calling for any kind of relativism, he urges the church to reach out to everyone." ([42], p. 1).

The role of the Church is seen by Pope Francis in terms of a movement from his own "center" (a self-referential attitude), in the context of a dynamic engagement, first and foremost, towards the world as it is and not in a strategic attempt to launch a sort of cultural reconquista. The relation between this idea of centralism and the invitation to "go outside" trigger a dialectical process that should be resolved in favor of a more open and committed attitude well beyond the invisible walls of the community of believers: "There is a tension between the center and the periphery. We must get out of ourselves and go toward the periphery. We must avoid the spiritual disease of the Church that can become self-referential: when this happens, the Church itself becomes sick. It's true that accidents can happen when you go out into the street, as can happen to any man or woman. But if the Church remains closed onto itself, self-referential, it grows old. Between a Church that goes into the street and 
gets into an accident and a Church that is sick with self-referentiality, I have no doubts in preferring the first."[46]. In Pope Francis' view risk aversion makes the Church sclerotic and eventually mummified. "Accidents" are preferable to "sickness".

\subsection{Periphery and the Theory of "Dependencia"}

As it has been noted, the language of Benedict XVI was that of Western modernity, acknowledging from the one side the pluralism of worldviews in contemporary societies, denouncing, from the other, the "dictatorship of relativism". The language of Francis, while recognizing the many challenges of cultural modernity, problematizes at the same time a process of social and economic polarization occurring at a global scale, at an increasing pace and with a growing intensity. However, it would be simplistic to trace back the root of this political discourse in the Latin American vision based on the "dependencia" theory developed by radical theorists in the 1970s and 1980s, such as Andre Gunder Frank [47] Samir Amin [48] or more moderated thinkers like Fernando Henrique Cardoso [49]. The theory of dependencia falls into the contemporary debates that take place inside the International Political Economy, and has to do with underdevelopment rather than with modernity as such in its cultural features. For these thinkers, underdevelopment is caused by factors that lay outside the control of the poor countries, in a sort of global division of labor in which the "third world countries" were condemned to rely on traditional exports (food, raw materials, energy) being cut off from the main circuit of innovation and technological development commanded by few capitalist powers. The recipes suggested by the theorists of the dependencia were not necessarily successful or even economically sustainable in the long run, sometimes leading to several nuanced versions of the ancient practice of mercantilism (as opposed to the liberal approach based on free trade) in order to allow the development of an internal production for an internal market. Global capitalist, in this view, "is supposed to sweep all of humanity into the circuits of a functionally differentiated global society. Yet Francis speaks of the total exclusion of entire nations and societies, and, what is more, that this is occurring in the shadow of modernity itself" [50].

\subsection{Periphery and the Theory of the World-System}

Despite the terminological similarities, it would be equally misleading, in the process of understanding the implications of Pope Francis' discourse on "peripheries", to refer to Wallerstein's grand theory on the dialectics between centre and periphery in the interpretation of the modern word-system. [51]. According to Wallerstein, there are three basic types of social systems: "mini-systems", that is small, homogenous societies, that ensure their survival through hunting and gathering or through pastoral activities, producing and consuming all goods and services within the sociocultural system itself; "world empires" that base their economies on the extraction of surplus goods and services from territories and societies situated outside the center, where operates a strong structure of political power that exerts domination; "world-economies" without a unified political system (present in the case of world-empires) and with no pretense of dominance based on military power alone, although these systems are still relying on the extraction of surplus from other external entities. 
In this general framework of analysis, Wallerstein divides the capitalist world-economy into core states, semi-peripheral, and peripheral areas.

The peripheral areas are the least developed and they are exploited by the core for their "favorable" working conditions (law salaries and poor social protection) and for being the providers of raw materials and other primary productions, mainly agricultural. The semi-peripheral areas are located at a medium distance between the peripheral areas and the core: from the one side, they are exploited by the core; from the other, they also play a role in the exploitation of the peripheral areas.

The core states are political and economic systems situated in geographically advantaged areas of the world-Europe and North America; they promote capital accumulation internally through several economic measures (tax recollection and forms of redistribution, public investments, especially in infrastructures), and try to minimize class struggle in order to reproduce the existing social order.

However, there are internal contradictions in this unequal distribution of power and roles between nation states, which might be contested and even lead to political and economic instability and social unrest. Eventually, in Wallerstein's view, a worldwide economic crisis will occur causing the collapse of capitalist world-system collapse and opening the way for revolutionary change.

Beyond the merits of Wallerstein's theory as an interpretative paradigm of the world (dis)order, there is a clear and profound difference between this dialectical vision of the world economy and the concept of periphery used by Pope Francis. In the Pope's view, a periphery is not only and not necessarily an historical and economic reality, since it implies also some ideational meaning unrelated to economic conditions or structural factors in a neo-Marxist appraisal of the shortcomings of the globalization. Moreover, a periphery can reproduce itself inside the capitalist world and becoming a painful reality within the core of the global economy. Peripheries are, in that view, a challenge to the integrative conception of the world, inside a political system and between political systems; if not dealt with, peripheries could become stable and solid realities, not leading to any change in the structure of global power.

\subsection{Periphery, Exclusion and Expulsion}

In Francis' discourse on periphery, one recurring feature is that of inclusion, as opposed to exclusion. Exclusion, in its essence implies two parallel destructive and intrinsically violent actions: first, targeting the process of "binding", second, omitting the process of "separating". In the conceptualization of Miroslav Volf, "first, exclusion can entail cutting of the bonds that connect, taking oneself out of the pattern of interdependence and placing oneself in a position of sovereign independence. The other then emerges either as an enemy that must be pushed away from the self and driven out of its space or as a nonentity - a superfluous being - that can be disregarded and abandoned. Second, exclusion can entail erasure of separation, not recognizing the other as someone who in his or her otherness belongs to the patterns of interdependence. The other then emerges as an inferior being who must either be assimilated by being made like the self or be subjugated to the self. Exclusion takes place when the violence of expulsion, assimilation, or subjugation and the indifference of abandonment replace the dynamics of taking in and keeping out as well as the mutuality of giving and receiving" [52]. The violence embedded in the processes that lead to different forms of exclusion helps understanding the real critical condition of the periphery. This circumstance explains why Pope Francis 
represents exclusion in a rather dramatic tone, as a potentially lethal social disease: "Just as the commandment 'Thou shalt not kill' sets a clear limit in order to safeguard the value of human life, today we also have to say 'thou shalt not' to an economy of exclusion and inequality. Such an economy kills. How can it be that it is not a news item when an elderly homeless person dies of exposure, but it is news when the stock market loses two points? This is a case of exclusion. Can we continue to stand by when food is thrown away while people are starving? This is a case of inequality. Today everything comes under the laws of competition and the survival of the fittest, where the powerful feed upon the powerless. As a consequence, masses of people find themselves excluded and marginalized: without work, without possibilities, without any means of escape. Human beings are themselves considered consumer goods to be used and then discarded. We have created a 'throw away' culture, which is now spreading. It is no longer simply about exploitation and oppression, but something new. Exclusion ultimately has to do with what it means to be a part of the society in which we live; those excluded are no longer society's underside or its fringes or its disenfranchised - they are no longer even a part of it. The excluded are not the 'exploited' but the outcast, the 'leftovers'." ([38], p. 45, paragraph 53).

Besides the powerful concept of exclusion, equally relevant in this process of deepening the idea of periphery in Pope Francis' discourse, is the work of Saskia Sassen on the concept of expulsion. In her words, the reference to the expelled "describes a diversity of conditions. They include the growing numbers of the abjectly poor, of the displaced in poor countries who are warehoused in formal and informal refugee camps, of the minoritized and persecuted in rich countries who are warehoused in prisons, of workers whose bodies are destroyed on the job and rendered useless at far too young an age, of able-bodied 'surplus populations' warehoused in ghettoes and slums. My argument is that this massive expulsion is actually signaling a deeper systemic transformation. It is an overarching dynamic that is taking us into a new phase of global capitalism" [53]. Pope Francis makes his own case advocating in favor of the expelled: "It is essential to draw near to new forms of poverty and vulnerability, in which we are called to recognize the suffering Christ, even if this appears to bring us no tangible and immediate benefits. I think of the homeless, the addicted, refugees, indigenous peoples, the elderly who are increasingly isolated and abandoned, and many others. Migrants present a particular challenge for me, since I am the pastor of a Church without frontiers, a Church which considers herself mother to all." ([38], p. 164, paragraph 210).

As Richard Falks points out, the present state of the world is defined as "inhumane globalization", in which polarization and global apartheid, neglect of human suffering, decline of the global public good, looming technological horizons are becoming the recurrent features of the prevailing social, economic and political model (see [27], pp. 147-50). "In such a global setting-writes Falk - the opportunity for and the responsibility of religion becomes evident, to provide hope for emancipation and, in effect, give a spiritual ground toward global democracy and humane globalization. Religious hope of this nature can be influential at all levels of social interaction, from the very local, to the planetary, and even the cosmic, encouraging a reconstructive post-modernism dedicated to finding the ideas and energies for a sustainable world that affirms the sacredness of life." ([27], p. 160). 


\section{Conclusions}

The very concepts of exclusion and expulsion seems to me closely related to Pope Francis' narrative on periphery; they provides a strong paradigms to understand the human implications and shortcomings of globalization in a much more accurate and concrete way than the vast systemic theories of empires and world economy, useful as they may be.

However, one should resist the temptation to reductively read Pope Francis approach as some sort of revised version of the "liberation theology" made fully compatible with the Catholic doxa and adapted to the global era. The idea of periphery represents an updated revised version of the "preferential option for the poor"; it implied not only "to hear the cry of the poor", but, at the same time, challenging the "trickle-down theories which assume that economic growth, encouraged by a free market, will inevitably succeed in bringing about greater justice and inclusiveness in the world. This opinion, which has never been confirmed by the facts, expresses a crude and naïve trust in the goodness of those wielding economic power and in the sacralized workings of the prevailing economic system. Meanwhile, the excluded are still waiting. To sustain a lifestyle which excludes others, or to sustain enthusiasm for that selfish ideal, a globalization of indifference has developed. Almost without being aware of it, we end up being incapable of feeling compassion at the outcry of the poor, weeping for other people's pain, and feeling a need to help them, as though all this were someone else's responsibility and not our own" ([38], p. 46, paragraph 54).

The central argument is not simply shedding light on the peripheries, it is rather to re-conceptualizing the world order from the vantage point of its numerous and diversified peripheries, not confined to a geographical region of the world or as a monopoly of a social category.

One spatial metaphor used by Pope Francis may be of some help in clarifying this fundamental change of perspective, at the same time integrated and pluralistic.

Francis makes clear that he doesn't see the world as a pyramid, as it happens in neo-Marxist scheme, even less as a sphere, as it is the case in the imaginary of the liberal globalization. He defends a more nuanced vision of a world interconnected - in the sense of neighboring human communities - yet without a dominant center, whose units are, to some extent, equally peripheral: "Here our model is not the sphere, which is no greater than its parts, where every point is equidistant from the centre, and there are no differences between them. Instead, it is the polyhedron, which reflects the convergence of all its parts, each of which preserves its distinctiveness." ([38], 177-78, paragraph 236).

This idea of convergence preserving distinctions reconnects to the dilemma between particularism and universalism in the visions of world community. It is a problem that involves not only the political critique of globalization but also affects, more radically, the task of "thinking difference" [54] in the international relations by revisiting the "geo-cultural epistemologies" of the paradigms used to analyze world politics and by de-colonizing the way we understand the ambivalent concepts of center and periphery.

\section{Acknowledgments}

Many thanks to Olivier Roy, Director of the Programme "ReligioWest"-Robert Schuman Centre for Advanced Studies, European University Institute, for the academic support I received by him and 
his excellent and multinational team. I also want to acknowledge the Programme "Religions in the Global World" (RGW) at Sophia University Institute (Incisa Valdarno), and in particular its Director Bernhard Callebaut, as well as its Coordinator Paolo Frizzi and the group of Research Fellows: Roberto Catalano, Vincenzo Di Pilato, Donald W. Mitchell, Rev. Nissho Takeuchi, Kin Sheung Chiaretto Yan.

\section{Conflicts of Interest}

The author declares no conflict of interest.

\section{References}

1. Gilles Kepel. The Revenge of God: The Resurgence of Islam, Christianity and Judaism in the Modern World. Oxford: Polity, 1993.

2. José Casanova. Public Religions in the Modern World. Chicago: University of Chicago Press, 1994.

3. Peter L. Berger. The Desecularization of the World: Resurgent Religions and World Politics. Washington: Ethics and Public Policy Center, 1999.

4. Fabio Petito, and Pavlos Hatzopoulos. Religion in International Relations: The Return from Exile. New York: Palgrave MacMillan, 2003.

5. Scott Thomas. The Global Resurgence of Religion and the Transformation of International Relations. New York: Palgrave, 2005.

6. Douglas Johnston, and Cynthia Sampson. Religion, the Missing Dimension of Statecraft. Oxford and New York: Oxford University Press, 1994.

7. Eric O. Hanson. Religion and Politics in the International System Today. Cambridge: Cambridge University Press, 2006.

8. Jeffrey Haynes. Introduction to International Relations and Religion. Harlow: Pearson Longman, 2007.

9. Jeffrey Haynes. Religion in Global Politics. Harlow: Longman, 1998.

10. Monica Duffy Toft, Daniel Philpott, and Timothy Samuel Shah. God's Century. Resurgent Religion and Global Politics. New York and London: W.W. Norton \& Company, 2011.

11. Timothy Samuel Shah, Alfred Stepan, and Monica Duffy Toft. Rethinking Religion and World Affair. Oxford: Oxford University Press, 2012.

12. Olivier Roy. Holy Ignorance: When Religion and Culture Part Ways. New York: Columbia University Press, 2010.

13. Gabriel A. Almond, R. Scott Appleby, and Emmanuel Sivan. Strong Religion: The Rise of Fundamentalisms around the World. Chicago: University of Chicago Press, 2003.

14. R. Scott Appleby. The Ambivalence of the Sacred: Religion, Violence and Reconciliation. New York: Carnegie Corporation, 2000.

15. Daniel Philpott. "Explaining the Political Ambivalence of Religion". American Political Science Review 101 (2007): 505-25.

16. David Martin Jones, and Martin Lawrence Rowan Smith. Sacred Violence. Political Religion in a Secular Age. New York: Palgrave MacMillan, 2014.

17. William T. Cavanaugh. The Myth of Religious Violence. New York: Oxford University Press, 2009. 
18. William Bole, Drew Christiansen, and Robert T. Hennemeyer. Forgiveness in International Politics. Washington: US Conference of Catholic Bishops, 2004.

19. David R. Smock. Interfaith Dialogue and Peacebuilding. Washington: US Institute for Peace Press, 2002.

20. Cyntia Sampson. "Religion and Peacebuilding." In Peacemaking in International Conflict: Methods and Techniques. Edited by I. William Zartman. Washington: US Institute of Peace, 2007.

21. Marc Gopin. Holy War, Holy Peace. How Religion Can Bring Peace in the Middle East. Oxford: Oxford University Press, 2002.

22. Peter Mandaville. "Reimagining Islam in Diaspora: The Politics of Mediated Community." International Communication Gazette 63 (2001): 169-86.

23. Jocelyne Cesar. Religion and Diasporas: Challenges of the Emigration Countries. Florence: European University Institute and Robert Schuman Centre for Advanced Studies, 2013.

24. Pasquale Ferrara. Global Religions and International Relations. A Diplomatic Perspective. New York: Palgrave MacMillan, 2014.

25. Ninian Smart. "The Global Future of Religion.” In Global Religions: An Introduction. Edited by Mark Juergensmeyer. New York: Oxford University Press, 2003.

26. Mark Juergensmeyer. Global Religions. New York: Oxford University Press, 2003.

27. Silvio Ferrari. "Tra geo-diritti e teo-diritti. Riflessioni sulle religioni come centri transnazionali d'identità." Quaderni di Diritto e Politica Ecclesiastica XV (2007): 3-14.

28. Andrew Linklater. The Transformation of Political Community. Cambridge: Polity Press, 1998.

29. Richard Falk. The Declining World Order. America's Imperial Geopolitics. New York and London: Routledge, 2004.

30. Michális S. Michael, and Fabio Petito. Civilizational Dialogue and World Order: The Other Politics of Cultures, Religions, and Civilizations in International Politics. New York: Palgrave Macmillan, 2009.

31. Mona Kanwal Sheikh. "How Does Religion Matter? Pathways to Religion in International Relations." Review of International Studies 38 (2012): 365-92.

32. John L. Esposito, and Michael Watson. Religion and Global Order. Cardiff: University of Wales Press, 2000.

33. Jens Bartelson. Visions of World Community. Cambridge: Cambridge University Press, 2009, p. 181.

34. Sergei Prozorov. "Generic universalism in world politics: Beyond international anarchy and the world state." International Theory 1 (2009): 215-16.

35. Hedley Bull. The Anarchical Society. A Study of Orders in World Politics. New York: Columbia University Press, 1977.

36. Dietrich Bonhoeffer. The Cost of Discipleship. New York: Touchstone 1995.

37. Gillian Brock, and Harry Brighouse (eds). The Political Philosophy of Cosmopolitanism. Cambridge: Cambridge University Press, 2005.

38. Pope Francis. "Evangelii Gaudium." Available online: http://w2.vatican.va/content/dam/ francesco/pdf/apost_exhortations/documents/papa-francesco_esortazione-ap_20131124_ evangelii-gaudium_en.pdf (accessed on 10 January 2015).

39. Mark Juergensmeyer. Global Rebellion. Religious Challenges to the Secular State, from Christian Militias to al Qaeda. Berkeley and Los Angeles: University of California Press, 2008. 
40. Ronald Robertson. "Antiglobal Religion.” In Global Religions. Edited by Mark Juergensmeyer. New York: Oxford University Press, 2003, pp. 110-23.

41. Philip Pullella. "New Pope Francis's first words after election." Reuters, 13 March 2013. Available online: http://www.reuters.com/article/2013/03/13/us-pope-succession-textidUSBRE92C19Y20130313 (accessed on 10 January 2015).

42. Pope John Paul II. "Discorso." 16 October 1978. Available online: http://www.vatican.va/ holy_father/john_paul_ii/speeches/1978/documents/hf_jp-ii_spe_19781016_primo-saluto_it.html (accessed on 10 January 2015) (In Italian).

43. Philip Jenkins. "A Peripheral Vision.” Available online: http://www.patheos.com/blogs/ anxiousbench/2014/02/a-peripheral-vision/ (accessed on 10 January 2015).

44. Antonio Spadaro S.J. "Wake up the World. Conversation with Pope Francis about Religious Life." La Civilità Cattolica I (2014): 3-17. English translation of the original text in Italian by Fr. Donald Maldari S.J.

45. Pope Francis. "Remarks at the pre-Conclave General Congregation meetings of the Cardinals." Available online: http://en.radiovaticana.va/storico/2013/03/27/bergoglios_intervention_a diagnosis_of_the_problems_in_the_church/en1-677269 (accessed on 9 March 2013).

46. Andrea Tornielli. "Tentazione sudamericana per il primo Papa extraeuropeo." Interview with Cardinal Jorge Bergoglio. La Stampa, 2 March 2013. Available online: http://vaticaninsider. lastampa.it/inchieste-ed-interviste/dettaglio-articolo/articolo/conclave-22809/ (accessed on 10 January 2015).

47. Andre Gunder Frank. Capitalism and Underdevelopment in Latin America. New York: Monthly Review Press, 1967.

48. Samir Amin. Unequal Development. Sussex: Harvester Press, 1976.

49. Fernando Henrique Cardoso, and Enzo Faletto. Dependency and Development in Latin America. Berkeley: University of California Press, 1979.

50. Randy David. "The Language of Pope Francis." Philippine Daily Inquirer, 13 April 2014. Available online: http://opinion.inquirer.net/73578/the-language-of-pope-francis (accessed on 10 January 2015).

51. Immanuel Wallerstein. The Modern World System I. New York: Academic Press, 1974.

52. Miroslav Volf. Exclusion and Embrace. Nashville: Abingdon Press, 1996, p. 67.

53. Saskia Sassen. "Expelled: Humans in Capitalism's Deepening Crisis." American Sociological Association 19 (2013): 198-201.

54. Arlen B. Tickner, and David L. Blaney. Thinking International Relations Differently. New York: Routledge, 2012.

(C) 2015 by the author; licensee MDPI, Basel, Switzerland. This article is an open access article distributed under the terms and conditions of the Creative Commons Attribution license (http://creativecommons.org/licenses/by/4.0/). 